\title{
Assessment of Marine Pollution at Bay of Oran, Algeria
}

\author{
Karima Baghdad ${ }^{*}$, Abdelaziz Bendraoua2 ${ }^{2}$, Abdelkrim Mohammed Hasnaoui1 \\ ${ }^{1}$ University of Oran 1, Ahmed Ben Bella, Oran, Algeria \\ ${ }^{2}$ University of Science and Technology, Oran, Algeria \\ Email: *arwachime@yahoo.f
}

Received 2 July 2015; accepted 6 September 2015; published 9 September 2015

Copyright $@ 2015$ by authors and Scientific Research Publishing Inc.

This work is licensed under the Creative Commons Attribution-NonCommercial International License (CC BY-NC).

http://creativecommons.org/licenses/by-nc/4.0/

(c) () (9) Open Access

\section{Abstract}

This work aims to the assessment of marine pollution in the Bay of Oran, including zinc, copper, iron and lead. These toxic elements represent a real danger to living organisms. Many factors have increased the marine pollution and marine traffic including the transport of hydrocarbons, industrial and domestic discharges and fishing activities, etc. This study shows essentially the bioconcentration of heavy metals in the species Mytilus galloprovincialis, these filter bivalves have a broad geographical distribution in our study area, so they allow us to better estimate the degree of pollution at the Bay of Oran. The study of changes in metal concentrations has marked some important points for, the four metallic elements are present in the flesh of mussels analyzed at the port of Oran. This study is part of assessment of pollution at the coast of western Algeria to protect the marine environment.

\section{Keywords}

Wastewater, Pollution, Chemical Pollution, Heavy Metals, Mussels Mytilus galloprovincialis, Littora

\section{Introduction}

Our study is part of the monitoring of coastal western Algeria; it's a marine pollution study including heavy metal at the port of Oran. This project uses mussel as tools for determination of this pollution, hence the followed method have been proposed for the first time, in the world, by Goldberg in 1975, under the term "Mussel Watch". This proposal has been implemented successfully in two types of strategies: those that use the native

${ }^{*}$ Corresponding author. 
populations of wild or cultivated mussels (bio passive monitoring) and those who have recourse to transplants of individuals from a reference site considered as less polluted place (bio active monitoring). Several researchers have used the mussel as a bio-indicator, in this context we can cite that the mussel Mytilus edulisis used to assess the mercury at the French coastline [1]; another research is based on studying of the ecotoxicology of heavy metals (cadmium, copper, lead, zinc) in the mussel Mytilus galloprovincialis in the Bay of Bourgneuf, France [2]; the authors in [3] studied the relationship between the availability of heavy metals in sediments and their accumulation by the mussel Mytulis edulis.

Other researchers have chosen to study two different marine species sharing the same habitat to better interpret the results [4], they are based on the evaluation of all metal content (not only heavy metals). This study took place at Eckwarderhorne, Cuxhaven/Altenbruch and Königshafen and the Baltic Sea (Germany), using these two species Fucus vesicdosus and Mytilus edulis. Moreover the mussel Perna viridis is chosen to study the accumulation of organic pollution, the results are compared with the accumulation in fish Lateolabrax japonicus, Pagrasomus magor, Miichthys miiuy and Epinephalus awoara [5].

Urban and industrial activities located on the coast, introduce a significant amount of heavy metals in the marine environment, the study of the impact of this pollution is the subject of many studies [5]-[8]. In order to assess the level of pollution in bays, the mussel Mytilus galloprovincialis L. 1758 is used for biomonitoring of Turkish bay [9]. These molluscs can be used to assess the metal and chemical pollution [10]-[14] and to evaluate their toxic effect in mice [15].

The genus Mytilus is widely used for several reasons: wide distribution, long life, reasonable size, a high tolerance for accumulation [16] [17], the mussels are less immigrants, their life is sessile and euryhaline [18], so their reproduction is continuous [19]. For the aquatic organisms, bioaccumulation of metals can have three sources: water, food and sediment, moreover, the penetration of mussels thus through their gills or by absorption at the surface of body [20].

The present work focuses on the assessment of the degree of pollution and contamination through the concentrations of metals $(\mathrm{Pb}, \mathrm{Cu}, \mathrm{Zn}$, and $\mathrm{Fe})$ in mussels.

\section{Location of Study Site}

Algeria has a coastline of $1200 \mathrm{~km}$ along 11 commercial ports which offer a chance for the competitiveness of the national economy, because the sea is the axis of the less expensive goods, as well as Algeria enjoys a privileged geographical position.

Our study area is the port of Oran, situated at the bottom of golf, between the tip of Canastel and Cape Falcon northwest of Ain el Turk. It offers a water level of more than 122 hectares, left eight basins. Solid land occupies an area of 200,000 $\mathrm{m}^{2}$ and shops Storage 20,332 $\mathrm{m}^{2}$ [21].

The port of Oran has a location in the foreground: Height: 35.43 North, Longitude: 0.39 west.

The choice of sampling site is based in part on the ease of access, the abundance of species and secondly on its proximity to sources of pollution(the main sewage outfall of the city of Oran, hot water from the power plant); Port of Oran has geostrategic position, industrial and commercial importance (Figure 1).

\section{Materials and Methods}

\subsection{Sampling and Analysis}

Fishing for these mollusk is performed on bedrock at depths not exceeding 10 meters, mussels collected is cleared of various wastes, sediments and algae all glued to their shells; are then stored and transported in a cooler filled the sea water, then they are stored at $-4^{\circ} \mathrm{C}$ until the day of analysis.

The mussel was been collected is a period of six-month (February, March, April, May, June, July) 2010, and each sample was consisted of 30 - 40 individual, measuring 2 to $7 \mathrm{~cm}$ (mean $4 \mathrm{~cm}$ ). The following parameters are considered: sampling date, station, size, and weather data.

After cleaned out theirs stomach, the mussels were sorted by size. The flesh is weigh and dried in an oven at $80^{\circ} \mathrm{C}$ to constant weight, after drying, the mussel was finely grounded; the grinding is performed in a laboratory agate mortar to obtain a powder light brown called dry powder mussel.

The metals are extracted after mineralization, which was ensured by an attack by the nitric acid and hydrochloric acid (V/V), three test of $50 \mathrm{mg}$ dry powder mussel were taken and mineralized for one hour at a tempera- 


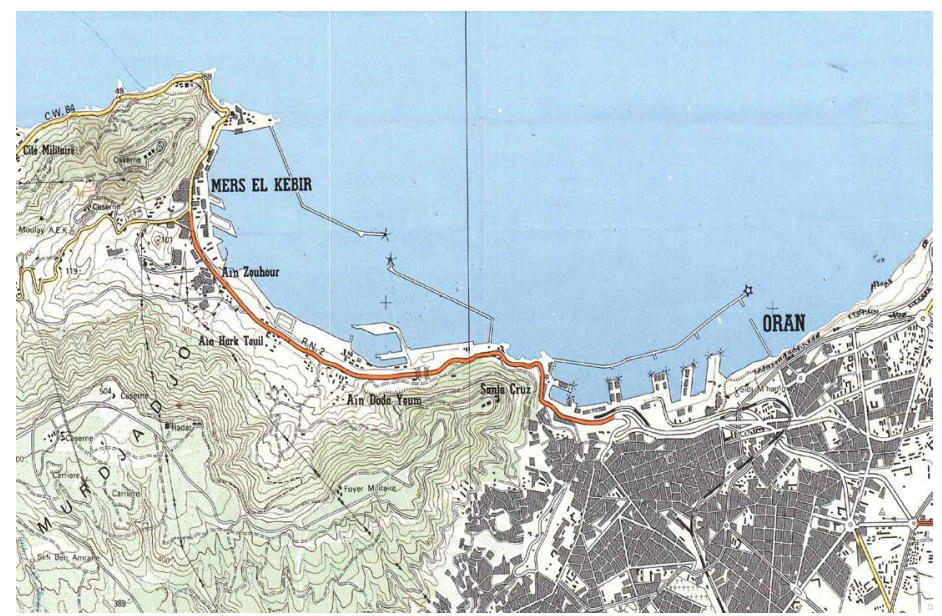

(a)

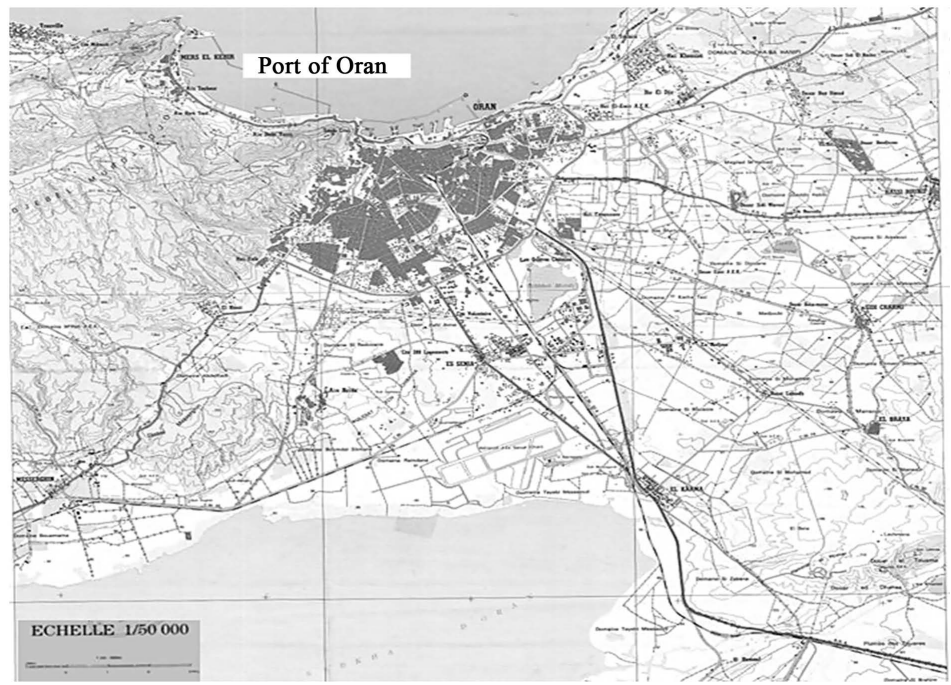

(b)

Figure 1. Location of sampling sites (Port of Oran-Algeria) (a), (b).

ture of $120^{\circ} \mathrm{C}$. The solution obtained is recovered after cooling of the glassware (risk of thermal shock) once rinsed with water double distilled to recover the maximum amount of sample water, everything was put into a glass bottles sealed and stored (to avoid loss and evaporation) to the assay by the method of atomic absorption spectrometry (AAS).

Mean concentrations are expressed in part per million (ppm) relative to 1 gram of the dry powder of mussels $\operatorname{ppm}(\mathrm{dw})$.

For more precision and clarity in the development of our results and to conduct a thorough interpretation we studied the concentrations found in mussels "Mytilusgalloprovincialis" according to two size groups: Group 1 (45 - $70 \mathrm{~mm}$ ), Group 2 (20 - $44 \mathrm{~mm})$.

\subsection{Statistical Analysis}

The variability of the metal contents was studied by analysis of variance of two factors (monthly and size) performed by the Student test; $\mathrm{n}$ roughly 12 (n: it's mean the effective number of our samples for each month).

\section{Results and Discussion}

Practically, during the winter, spring and summer, we noticed the existence of a fluctuation justified primarily 
by the influence of climate parameters, resting on the rate of precipitation that changes from one season to another, the speed and direction of wind, if we take for example the winter season, The days planned for sampling are accompanied by a more or less considerable precipitation, the latter is practically zero for the other seasons. For the second parameter which is obviously the biological species selected, indeed, mussels are filtermarine molluscs (filter up to 100 liters of water per day). They can bio accumulate more organic contaminants and respond particularly well to the main classes of environmental pollutants [22] (Figure 2).

As all trace metals $(\mathrm{Pb}, \mathrm{Zn}, \mathrm{Cd}, \mathrm{Cu})$ were present, so we assume that contamination of marine waters by these elements exists, but estimating their impact remains limited. Moreover, we can cite some works that have been the subject of study of biological stress caused by concentrations that generally exceed the maximum permissible doses (DMA) [23] [24], In addition, the study of biological stress and biomarkers is a new approach, moving beyond traditional methods to evaluate the quality of the environment and the danger of consumption of these species [25].

The results obtained show that there is more or less considerable difference between sizes of mussels selected where the metals studied appear to be more accumulated in mussels Group 2 (20 - $44 \mathrm{~mm})$, that are younger. Furthermore, the size of the mussel has the influence on their metal accumulation and particularly in the ripening periods [26]. We recorded periods of rising and falling concentrations of the metal element, the average values of lead and zinc are the most significant comparatively to the other metals, in addition, the maritime traffic is the main cause of the elevated levels of lead [27]. Moreover, the degradation of the anti-fouling covering the hulls of ships, due to corrosion paint, justifies the high contents of lead and zinc [28].

For the essential metals such as copper and zinc, their accumulation is done in two ways: in a dissolved form or by ingestion of food [29]. Cadmium accumulates unlike only in dissolved form. This may also explain the high levels of Zinc. However, copper and zinc can be harmful when their concentration exceeds a certain threshold [30].
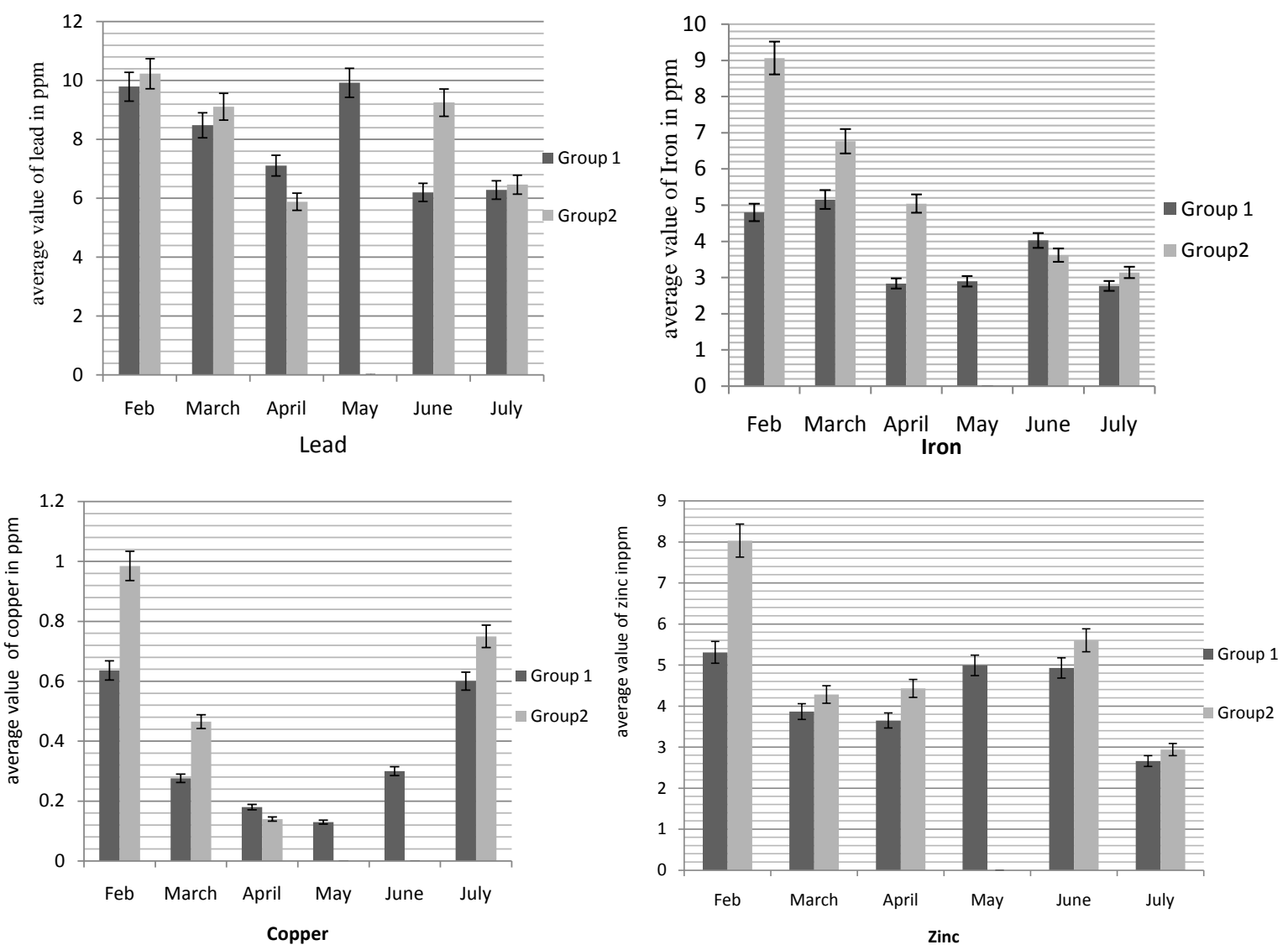

Figure 2. Variation of the average content of heavy metals. Group 1: the size of mussel "Mytilusgalloprovincialis” between $45 \mathrm{~mm}$ and $70 \mathrm{~mm}$; Group 2: the size of mussel "Mytilus galloprovincialis" between $20 \mathrm{~mm}$ and $44 \mathrm{~mm}$. 
The competitive of cadmium disrupts the absorption of copper, this may justify medium contents of copper and cadmium detected when their concentrations are generally close [6] [31].

The physico-chemical parameters of the environment have an effect on the accumulation of metals by organisms [3] [20]. During our study, we observed an increase in concentration of trace metals in February and March according to a maximum rainfall and consequently a decline in total salinity. Our findings are in agreement with the results of [20] [26] [27] [32]. They showed that the concentration tissue of Zn, Pb, Cd increased significantly with decreased salinity. In addition, the wastewater and temperature may also affect the salinity. Then, shipping is the major source of lead pollution [9].

Beside, the temperature and salinity have some influence on physiological processes related to metabolism and especially the reproduction [20], the mussels are the main target of contamination by trace metals and their ability to fix many toxic elements both inorganic and organic [33] [34].

So, the pollution of marine ecosystems is related with the production of marine toxins that concentrate in mussels which generates consumption poisoning in humans.

The results obtained at the port of Oran (Cadmium: $0.12 \mathrm{ppm}$; Copper: $1.16 \mathrm{ppm}$; Lead: $1.48 \mathrm{ppm}$ ) [35], showed a low contents then those founded in our study, especially as part the lead. Furthermore, the average concentration of the latter has undergone 5.3 times rise. This can be justified by the continuing evolution of the pollution, as well as changes in food resources or sexual status, and the choice of the sampling period which is a key factor.

Comparing our results with those obtained at the French coast, average lead concentrations recorded are much higher than indicated by the National Observation Network in 2003 (NON) (1.49 ppm.dw) (France).

\section{Comparison with Other Authors}

The mussels were the object of many studies; some of them are given in the Table 1 in order to compare them with our results.

Table 1 shows that the comparison of our results with those of other researchers. In the metal concentrations obtained for the mussel Mytilus galloprovincialis at the port of Oran, the concentrations of lead are the highest.

The analysis of variances performed on metal contents showed significant differences for all the metals studied, $p<0.05$.

\section{Conclusions}

According to the results presented, it seems that the oldest mussels are the least contaminated and the youngest mussels appear to be the target of these micropollutants, generally we have touched the monthly variation of bioaccumulation in mussels "Mytilus galloprovincialis".

The accumulation of these metals generally follows the following order: $\mathrm{Pb}>\mathrm{Zn}>\mathrm{Cd}>\mathrm{Cu}$.

\section{Acknowledgements}

The authors thank the divers and all members of associations: "Friends of the sea and Phynicia" and the Laboratory of Physical Chemistry of Materials, Catalysis and Environment at the University of Science and Technology

Table 1. Metal concentrations in ppm observed in molluscs*.

\begin{tabular}{cccccc}
\hline Authors Specie & Origin & Pb (ppm) & Cu (ppm) & Zn (ppm) & Cd (ppm) \\
\hline Tuncer and Mg Yaramaz ${ }^{* *}$ (1982) [36] & Bay of Izmir (Turkey) & 1.36 & 6.92 & 2791.1 \\
Asso $^{* *}$ (1984) [37] Pp & Bay of Algiers (Algeria) & 6.31 & 13.1 & 200 & 1.26 \\
Coimbra $^{* *}$ et al. (1991) [38] Me & Littoral of Portugais & - & 13.4 & 542 & 1.25 \\
Pempkowiak ${ }^{* *}$ et al. Me (1999) [39] & Sea of Baltic & 5.22 & 13.40 & 269 & - \\
Tahiri ${ }^{* * *}$ et al. (2005) [34] Mg & Bouregreg (Morocco) & 4.08 & 8.77 & 225 & 0.48 \\
Our study ${ }^{* * *}$ Mg & Port of Oran (Algeria) & 7.85 & 0.37 & 4.59 & 0.97 \\
\hline
\end{tabular}

*Me: Mytilus edulis; Pp: Perna perna; Mg: Mytilus galloprovincialis. ${ }^{* *}$ The value of P for the statistical analysis it's not mentioned. ${ }^{* * *}$ The value of $\mathrm{P}$ for the statistical analysis is $<0.05$. 
of Oran and Laboratory of GNL1 complex/Z (Sonatrach) which have been performed all physico-chemical analyses and those of metals reported in this study.

\section{References}

[1] Thibaud, Y. (1973) Mercury Content in the Mussel of the French Coastline, Fishing and Science. No. 221.

[2] Amiard, J.C., Amiard-Triquet, C., Berthet, B. and Metayer, C. (1986) Contribution to the Ecotoxicological Study of Cadmium, Lead, Copper and Zinc in the Mussel Mytilus edulis: I. Field Study. Marine Biology, 90, 425-431. http://dx.doi.org/10.1007/BF00428566

[3] Bourgoin, B.P., Risk, M.J., Evans, R.D. and Cornett, R.J. (1991) Relationships between the Partitioning of Lead in Sediments and Its Accumulation in the Marine Mussel, Mytilus edulis near a Lead Smelter. Water, Air, and Soil Pollution, 57-58, 377-386. http://dx.doi.org/10.1007/bf00282901

[4] Ostapczuk, P., Burow, M., May, K., Mohl, C., Froning, M., Subenbach, B., Waidmann, E. and Emons, H. (1997) Mussels and Algae as Bioindicators for Long-Term Tendencies of Element Pollution in Marine Ecosystems. Chemosphere, 34, 2049-2058.

[5] Klumpp, D.W., Huasheng, H., Humphrey, C., Xinhong, W. and Codi, S. (2002) Toxic Contaminants and Their Biological Effects in Coastal Waters of Xiamen, China.: I. Organic Pollutants in Mussel and Fish Tissues. Marine Pollution Bulletin, 44, 752-760. http://dx.doi.org/10.1016/S0025-326X(02)00053-X

[6] Kaimoussi, A., Chafik, A., Mouzdahir, A. and Bakkas, S. (2001) The Impact of Industrial Pollution on the JorfLasfar Coastal Zone (Morocco, Atlantic Ocean): The Mussel as an Indicator of Metal Contamination. Comptes Rendus de l'Académie des Sciences-Series IIA/Earth and Planetary Sciences, 333, 337-341.

[7] Gorinstein, S., Moncheva, S., Katrich, E., Toledo, F., Arancibia, P., Goshev, I. and Trakhtenberg, S. (2003) Antioxidants in the Black Mussel (Mytilus galloprovincialis) as an Indicator of Black Sea Coastal Pollution. Marine Pollution Bulletin, 46, 1317-1325. http://dx.doi.org/10.1016/S0025-326X(03)00239-X

[8] Maria Storelli, M. and Marcotrigiano, G.O. (2005) Bioindicator Organisms: Heavy Metal Pollution Evaluation in the Ionian Sea (Mediterranean Sea-Italy). Environmental Monitoring and Assessment, 102, 159-166. http://dx.doi.org/10.1007/s10661-005-6018-2

[9] Sunlu, U. (2006) Trace Metal Levels in Mussels (Mytilus galloprovincialis L. 1758) from Turkish Aegean Sea Coast. Environmental Monitoring and Assessment, 114, 273-286. http://dx.doi.org/10.1007/s10661-006-4780-4

[10] Kira, S., Izumi, T. and Ogata, M. (1983) Detection of Dibenzothiophene in Mussel, Mytilus edulis, as a Marker of Pollution by Organosulfur Compounds in a Marine Environment. Bulletin of Environmental Contamination and Toxicology, 31, 518-525. http://dx.doi.org/10.1007/BF01605468

[11] Corvi, C., Zimmerli, P., Ortelli, D., Khim-Heang, S., Van Slooten, K.B., Stegmueller, A.M. and Tarradellas, J. (1997) Metals and Organic Micro-Pollutants in Fish and Mussels of Lake Geneva. Report.comm.int.prot-waters Geneva against pollution, Companion 1997-1998, 103-116.

[12] Tanabe, S., Prudente, M.S., Kan-Atireklap, S. and Subramanian, A. (2000) Mussel Watch: Marine Pollution Monitoring of Butyltins and Organochlorines in Coastal Waters of Thailand, Philippines and India. Ocean \& Coastal Management, 43, 819-839. http://dx.doi.org/10.1016/S0964-5691(00)00060-0

[13] Monirith, I., Ueno, D., Takahashi, S., Nakata, H., Sudaryanto, A., Subramanian, A., Karuppiah, S., Ismail, A., Muchtar, M., Zheng, J., Richardson, B.J., Prudente, M., Hue, D.N., Tana, T.S., Tkalin, A.V. and Tanabe, S. (2003) Monitoring Contamination of Persistent Organochlorine Compounds in Coastal Waters of Asian Countries. Marine Pollution Bulletin, 46, 281-300. http://dx.doi.org/10.1016/S0025-326X(02)00400-9

[14] Shim, W.J., Hong, S.H., Kim, S.N., Yim, H.U., Li, D. and Oh, J.R. (2005) Assessment of Butyl- and Phenyltin Pollution in the Coastal Environment of Korea Using Mussels and Oysters. Marine Pollution Bulletin, 51, 922-931. http://dx.doi.org/10.1016/j.marpolbul.2005.07.015

[15] Moustaid, K., Nasser, B., Baudrimont, L., Anane, R., El Idrissi, M., Bouzidi, A. and Creppy, E. (2005) Comparative Evaluation of the Toxicity of Mussels (Mytilus galloprovincialis) from Two Sites of the Moroccan Atlantic Coast on Mice. Comptes Rendus Biologies, 328, 281-289. http://dx.doi.org/10.1016/j.crvi.2005.01.004

[16] Naimo, T.J. (1995) A Review of the Effects of Heavy Metals on Freshwater Mussels. Ecotoxicology, 4, 341-362. http://dx.doi.org/10.1007/BF00118870

[17] Jamil, A., Lajtha, K., Radan, S., Ruzsa, G., Cristofor, S. and Postolache, C. (1999) Mussels as Bioindicators of Trace Metal Pollution in the Danube Delta of Romania. Hydrobiologia, 392, 143-158. http://dx.doi.org/10.1023/A:1003555130831

[18] Cossa, D. and Lassus, P. (1989) The Cadmium in Marine, Biogeochemistry and Eco Toxicology. French Research In- 
stitute for Exploitation of the Sea Scientific and Technical Reports of the IFRE, MER Center of Brest, Brest.

[19] Naciri, M. (1998) Dynamics of a Population of Mussels Mytilus galloprovincialis (Lmk) Living on the Moroccan Atlantic Coast. Bulletin of the Scientific Institute Rabat, 21, 43-50.

[20] Cheggour, M. (1989) Bioaccumulation of Some Metallic Elements (Cu, Zn, Pb, Ni, Cr, Mn, Fe, V) in a Bivalve Mollusc, Scrobicularia Plana, in the Estuary of the Bouregreg (Moroccan Atlantic Coast). Bulletin of the Scientific Institute, 13, $125-133$.

[21] Grimes, S. and Boudjakdji, M. (1996) The Port Environment Pollution: Preliminary Notes on the Impact of Industrial and Domestic Pollution on Macrozoobenthos, Port of Oran. Proceedings of the 3rd National Conference, Climate and Environment, 5 p.

[22] Jurd, R.D. (2000) Mussels as Bioindicators of Trace Metal Pollution in the Danube Delta of Romania. Hydrobiologia, 392, 143-158. http://dx.doi.org/10.1023/A:1003555130831

[23] Amiard, J.C., Amiard-Triquet, C., Barka, S., Pellerin, J. and Rainbow, P.S. (2006) Metallothioneins in Aquatic Invertebrates: Their Role in Metal Detoxification and Their Use as Biomarkers. Aquatic Toxicology, 76, 160-202. http://dx.doi.org/10.1016/j.aquatox.2005.08.015

[24] Lowe, D.M., Fossato, V.U. and Depledge, M.H. (1995) Contaminant-Induced Lysosomal Membrane Damage in Blood Cells of Mussels Mytilus galloprovincialis from the Venice Lagoon: An in Vitro Study. Marine Ecology Progress Series, 129, 189-196. http://dx.doi.org/10.3354/meps129189

[25] Taleb, M.Z., Benali, I., Gherras, H., Ykhlef-Allal, A., Bachir-Bouiadjra, B., Amiard, J.C. and Boutiba, Z. (2009) Biomonitoring of Environmental Pollution on the Algerian West Coast Using Caged Mussels, Mytilus galloprovincialis. Oceanologia, 51, 63-84.

[26] Ritz, D.A., Swain, R. and Elliot, N.G. (1982) Use of the Mussel Mytilus edulis Planulatus (Lamarck) in Monitoring Heavy Metal Levels in Seawater. Marine and Freshwater Research, 33, 491-506. http://dx.doi.org/10.1071/MF9820491

[27] Phlllips, D.J.H. (1977) The Use of Biological Indicator Organisms to Monitor Trace Metal Pollution in Marine and Estuarine Environments-A Review. Environmental Pollution, 13, 281-317. http://dx.doi.org/10.1016/0013-9327(77)90047-7

[28] Augier, H. (1988) Threats to Populations of Sea Urchins. Océanorama, 12, 32-38.

[29] Wang, W.X. and Fisher, N.S. (1996) Assimilation of Trace Metal Elements and Carbon by the Mussel Mytilus edulis: Effects of Food Composition. Marine Biology, 125, 715-724.

[30] Poham, J.D. and D’auria, J.M.L. (1982) Effects of Season and Sea Water Concentrations on Trace Metal Concentrations in Organ of Mytilus edulis. Archives of Environmental Contamination and Toxicology, 11, 273-282.

[31] Ky, T., Guilbert, J.M. and Didou-Manet, M. (2003) Little Encyclopedia of Seafood. 8th Edition, the Green Wave, Paris, $212 \mathrm{p}$.

[32] Phillips, D.J.H. (1980) Quantitative Aquatic Biological Indicators: Their Use to Monitor Trace Metal and Organ Chlorine Pollution. Applied Science Publishers Ltd., London.

[33] Geffard, O. (2001) Potential Toxicity of Contaminated Marine and Estuarine Sediments: Chemical and Biological Evaluation Bioavailability of Sediment Contaminants. Thesis, University of Bordeaux, Bordeaux.

[34] Tahiri, L., Bennasser, L., Idrissi, L., Fekhaoui, M., El Abidi, A. and Mouradi, A. (2005) Metal Contamination of Mytilus galloprovincialis and Sediment at the Bouregreg Estuary (Morocco). Water Quality Research Journal of Canada, 40, 111-119.

[35] Taleb, M.Z. and Boutiba, Z. (2007) The Mussel Mytilus galloprovincialis: Bioindicator of Marine Pollution—Cases of Port d'Oran. Science \& Technology, No. 25, 59-64.

[36] Tuncer, S. and Yaramaz, O. (1982) Study of Heavy Metals in Molluscs in Different Areas of the Bay of Izmir (Turkish). Proceedings of the 5th Workshop on the Pollution (C.I.E.S.M.), Cannes, 307-313

[37] Asso, A. (1984) Study of Overall Levels of Heavy Metals in the Mussel Pernaperna (L) in the Algiers Region—Level's Variation with Some Biological Parameters. Proceedings of the 5th Workshop on the Pollution (C.I.E.S.M.), Lucerne.

[38] Coimbra, J., Carraca, S. and Ferreira, A. (1991) Metals in Mytilus edulis from the Northern Coast of Portugal. Marine Pollution Bulletin, 22, 249-253. http://dx.doi.org/10.1016/0025-326X(91)90920-N

[39] Pempkowiak, J., Sikora, A. and Biernacka, E. (1999) Speciation of Heavy Metals in Marine Sediments vs. Their Bioaccumulation by Mussels. Chemosphere, 39, 313-321. http://dx.doi.org/10.1016/S0045-6535(99)00112-5 